\title{
Entrepreneurial Imagination and a Demand and Supply-side Perspective on the MNE and Cross- border Organization
}

\section{Citation}

Jones, Geoffrey, and Christos Pitelis. "Entrepreneurial Imagination and a Demand and Supplyside Perspective on the MNE and Cross-border Organization." Journal of International Management 21, no. 4 (December 2015): 309-321.

\section{Published Version}

http://dx.doi.org/10.1016/j.intman.2015.07.003

\section{Permanent link}

http://nrs.harvard.edu/urn-3:HUL.InstRepos:30203375

\section{Terms of Use}

This article was downloaded from Harvard University's DASH repository, and is made available under the terms and conditions applicable to Open Access Policy Articles, as set forth at http:// nrs.harvard.edu/urn-3:HUL.InstRepos:dash.current.terms-of-use\#OAP

\section{Share Your Story}

The Harvard community has made this article openly available.

Please share how this access benefits you. Submit a story.

\section{Accessibility}




\title{
Entrepreneurial Imagination and a Demand and Supply- Side Perspective on the MNE and Cross-Border Organisation
}

\author{
Geoffrey Jones \\ Harvard Business School \\ gjones@hbs.edu \\ +1 (617) 495-6337 \\ Baker Library 175 \\ Boston, MA 02163, USA
}

Christos Pitelis*

University of Bath

cnp27@management.bath.ac.uk

+44 (0) 1225385311

Claverton Down, Bath BA2 7AY, United Kingdom

*Corresponding Author 


\begin{abstract}
We focus on supply and the under-explored demand-side factors that help explicate crossborder expansion, the Multinational Enterprise (MNE) and organization. We explore how appropriability-informed and legacy-shaped entrepreneurial imagination motivates a process of creation and co-creation of the cross-border business context (such as markets, demand, and supporting infrastructures, including business ecosystems), and when feasible the wider institutional, regulatory and even cultural one, that conventional International Business (IB) literature takes as a datum. This is examined conceptually and by drawing on illustrative case examples. We claim that by focusing on agency, learning, intentionality and demand-side factors, our approach complements, and also challenges extant sometimes static, supply-side, agent-agnostic theories of the MNE and helps appreciate better phenomena such as market, demand and value creation, and co-creation, MNEs without firm specific advantages and born-global firms.
\end{abstract}

Keywords: entrepreneurship, imagination, history, appropriability, market and demand creation, cross-border expansion and organisation, MNE 
"Imagination is more important than knowledge. For knowledge is limited to all we now know and understand, while imagination embraces the entire world, and all there ever will be to know and understand."

Albert Einstein (1931)

"Apple itself, which Jobs considered his greatest creation, a place where imagination was illustrated, applied and executed...."

Walter Isaacson (2011)

In critiquing the role of the multinational enterprise (MNE) in global organization and governance, Stephen Hymer (1972), arguably the father figure of the theory of the MNE and foreign direct investment (FDI), suggested that through what he called a 'correspondence principle', MNEs shape the world to their 'image', creating a hierarchical world order, involving 'superior' and 'inferior' states (a 'core' and a 'hinterland'), and even 'superior' and 'inferior' classes of peoples both within nations and cross-border (Dunning \& Pitelis, 2008).

Edith Penrose $(1955 ; 1959 / 2009)$, arguably the mother figure of the resource-based view (RBV) of the firm and the MNE, explained firm growth in terms of the concept of 'productive opportunity', defined as the dynamic interaction between the perceived external environment (such as demand and competition), and the internal one (such as resources and capabilities). Drawing on Boulding (1956), Penrose suggested that the perceived 'productive opportunity' of firms was an 'image' in the minds of entrepreneurial managers. That 'image', however, was formed in the context of a real-life history-based, path dependent, evolutionary change, shaped by purposive action by economic actors, notably entrepreneurs. 
Penrose also observed that "there would seem to be a complementarity between theory and history" (Penrose, 1989:11) and that "theory is needed precisely because reality is so complicated' (ibid). We submit that this observation is accurate, yet limited in that learning as a historico-theoretical process, shapes our very appreciation of reality, hence the 'productive opportunity', including the external environment, demand and competition (Pitelis, 2000). We employ such an augmented Penrosean lens in the remainder of this paper, for the case of cross-border expansion by firms and the Multinational Enterprise (MNE), noting that despite her extensive writings on the MNE and FDI, Penrose herself has not endeavoured to develop a theory of the MNE (Pitelis, 2011).

In particular, in this paper we pay attention to the actions and strategies that help firms create and co-create new markets, hence demand and potentially appropriable value, and a supporting business environment-ecosystem cross-border, that is the very business context which conventional theory of the MNE and FDI. In line with an extensive literature in organizations and management (see Teece, 2007), we emphasize the role of appropriability, namely the exploitation (value capture potential) of ideas and other advantages, through cross-border activities, and the way in which this motivates/triggers entrepreneurial imagination and actions that create and co-create appropriable value in the first place. In this sense we also answer calls to integrate demand and supply side, as well as value creation and value appropriation/capture approaches (Priem, Li \& Carr, 2012).

Scholarship on the nature of the MNE and entry modalities has for the most part not followed up the interest of contributors such as Penrose, in firm's path dependent imagining and acting upon opportunities. In part, this reflects the challenges of International Business (IB) scholarship to incorporate entrepreneurship in extant rather static and agent-less theories of the MNE and Foreign Direct Investment (FDI), see Doz (2004). This is despite, multiple 
contributions by Mark Casson. Casson's search for a theory of information-processing by individual entrepreneurs did not utilize the concept of 'imagination', but might have easily done so (Casson, 1982, 1995). Curiously, despite being a pioneer both of the theory of the MNE (Buckley and Casson, 1976) and entrepreneurship (Casson, 1982), he has only occasionally aimed to bring the two together (Casson, 1986). In all, and following the strictures of Zald (1996) and Jones and Khanna (2006), it might be argued that the dominant disciplinary and methodological paradigm in cross-border organization scholarship, could benefit by being more and better informed by history, agency and imagination.

In contrast to the mostly economics-informed theories of the MNE and FDI, works in International Management (IM) scholarship did emphasize the role of entrepreneurial and managerial agency and capabilities in addressing among others the potential tradeoffs between global integration and local adaptation (Bartlett \& Ghoshal, 1989), in leveraging subsidiary skills and competences (Hedlund, 1986, Birkinshaw \& Hood, 1998; Papanastassiou \& Pearce, 2009) and in explicating phenomena such as 'born global' firms (Oviatt \& McDougall, 1994; Knight \& Cavusgil 2004).

We briefly revisit some major contributions in the next section, and then we build upon their insights in trying to address and take further the Doz challenge. We note that interestingly, the more agency-rich approaches have not been applied to the issue of the nature of the MNE (why MNEs exist to start with), other than in the case of 'born globals' (Knight \& Cavusgil 2004). Related to the above, explanation of the role of entrepreneurs and entrepreneurial managers in shaping and indeed co-creating the business (and sometimes the wider socio-politico-economic) context to which Doz refers has arguably been underexplored. Recently Pitelis and Teece (2010) offered an entrepreneurial theory of the MNE that attributes its nature and essence to market and business ecosystem co-creation 
dynamic capabilities (DCs) that the authors define as the mother of all DCs. None of the above have considered the role of entrepreneurial imagination in explicating cross-border expansion, the nature of the MNE and cross-border organization, in an integrative way that accounts for demand and supply and value creation and value capture-our aim and scope in this article.

In contrast, in the management and entrepreneurship literature more generally, imagination has often been identified as important. Hamel and Prahalad (1991) for example, argued that 'corporate imagination' was the key to innovation. For the case of new ventures, Bhidé (2000), suggested that new venture entrepreneurs "have to use their imaginations to envision what their firms could become along several dimensions, such as the markets they will serve, the tangible and intangible efforts they will acquire, and their organization's climate and norms" (2000: 296). Cornelissen and Clarke (2010) also focused on new venture creation and legitimization by entrepreneurs. The authors drew on an extensive literature on entrepreneurship (such as Alvarez \& Barney, 2007) and cognitive and institutional research on entrepreneurial 'sensemaking' (notably Weick, 1995), in order to explain "how entrepreneurs imagine venture opportunities and how they simultaneously develop and legitimize new ventures to exploit such opportunities" (p.554). Research on entrepreneurial cognition has explored how entrepreneurial opportunities are not immediately apparent, but rather need to be perceived and enacted by individuals (Tripsas \& Gavetti, 2000). The importance of imagination also features prominently in the literature on entrepreneurial and managerial creativity (Amabile 1996; Osburn \& Mumford 2006; Tsang 2015). It is arguable that IB could benefit from cross-fertilization with such views.

While, to a certain extent, cross-border expansion can be regarded as a type of new venture, there are important additional considerations, challenges and themes pertinent to cross-border expansion, which we feel justify a separate focus. Important among these is the 
role of path dependence-based, but also importantly the managerial intentionality-based (Knight \& Cavusgil, 2004) cross-border creation and co-creation of the context within which theory has been traditionally developed. By context we refer to the business but also the institutional, regulatory and even cultural milieu faced by firms in host countries. While our attention here is mostly on the business context, we recognize and provide illustrative case example where firms have tried to shape and indeed create and co-create the wider context of their operations. In a brilliant account of the East India Company, Clegg (2016) shows how the extent to which the company has been able to do just that in the case of India.

Another major limitation of extant theory of the MNE and FDI relates to its scant attention to demand-side factors, importantly the very process of the extension, creation and co-creation of new markets, hence demand and appropriable value by MNEs, in its relationship to the supply-side (the main focus of extant theory). Despite a resurgence of demand-side ideas in management scholarship (Adner \& Zemsky, 2006; Priem et al., 2012, Levitas, 2013), and in marketing (Read, Dew, Saraswathy \& Wiltbank, 2009; Ramaswamy \& Gouillart, 2010), these have found little application in IB.

We build on the aforementioned literature and ideas, in order to provide a new perspective on cross-border expansion, the MNE and cross-border organization, based on the concepts of legacy-based imagined realities and the argument that entrepreneurs, motivated by appropriability, act on their path dependent and shaped 'images' to create and co-create demand and supply-side conditions, markets, and supporting business ecosystems (that is the very context) and hence appropriable value cross-border that help realize their 'images'/'visions'. This is particularly the case in today's fast shifting environments and 'productive opportunities', where Schumpeterian competition, based on novelty, creativity and innovation, has arguably replaced the earlier focus by Hymer (1960/1976) and Porter 
(1980) on rivalry reduction in largely stable and predictable environments. We claim that our approach helps complement extant work on the MNE and FDI, but also to challenge it and better explain phenomena such as market, demand and value creation and co-creation, 'born global' firms and MNEs without any apparent (differential) ownership advantages.

In terms of structure, in the next section we provide a short account of the theory of the MNE, highlighting the limited role afforded to entrepreneurial imagination (and agency) in it, context creation and in particular its demand-side. The third section introduces the concept of appropriability-informed and legacy-shaped entrepreneurial imagination, and examines its potential role in explicating cross-border expansion, not least though market, demand and hence value creation and co-creation by firms and the MNE. The fourth section draws on illustrative case examples that aim to elaborate and challenge our conceptual thesis that legacy-informed imagination and 'productive opportunity' can play a critical role in explaining the nature of the MNE (why do MNEs exist), as well as the pathways through which the demand and supply-side context of cross-border organization, which is often taken for granted in extant theory of the MNE and FDI is shaped. The last section provides a concluding discussion with limitations and avenues for further research.

\section{EXTANT THEORY OF CROSS-BORDER EXPANSION, THE MNE AND CROSS- BORDER ORGANISATION}

\subsection{Supply-Side Theory}

Despite a long history of writings on the MNE and cross-border organization preHymer (Buckley, 2010), the origins of the modern theory of the MNE and FDI are usually traced to Stephen Hymer's (1960/1976) PhD thesis. Hymer asked the question why crossborder integration through FDI is selected by firms over potential less hierarchical alternatives, such as licensing to foreign firms, for the exploitation of an advantage. Hymer 
felt that FDI afforded to firms better returns on their (in his view monopolistic) advantages. In addition, as noted, he felt that FDI helped reduce cross-border inter-firm rivalry, and served as a means of inter-national risk diversification.

The major post-Hymer contributions were the theory of 'internalization' of advantages as a result of high market transaction costs, and more recently the evolutionary, resource-based and/or dynamic capabilities (DCs) views. Both focus on mostly supply-side efficiency-related reasons for 'internalization'. Classic contributions on 'internalization' include Buckley and Casson (1976), who emphasized intermediate product market failures, and Williamson (1981), who emphasized bilateral interdependencies and hold-ups, induced by asset specificity. Teece (1976) focused on differential resource-transfer costs cross-border, while Hennart (1982) suggested that the MNE could be seen as an organization that coordinates cross-border interdependencies more efficiently through employment relationships than through output markets, and more recently as cross-border asset bundlers (Hennart, 2009).

The evolutionary, resource-based and learning-dynamic-capabilities perspective drew on works by Penrose (1959/2009), as developed and integrated with transaction costs arguments (Teece, 1981, 1982), the partly Penrose-inspired work of the Scandinavian school (Johanson \& Vahlne, 2009) that emphasizes learning and the role of 'psychic distance' and more recently 'outsideness', the 'evolutionary theory' of Kogut \& Zander (1993), which emphasizes the importance of knowledge and advantages of its intra-organisational versus inter-organizational transfer, and the 'technological accumulation' approach of John Cantwell (1989). The resource-based and learning-dynamic-capabilities perspectives emphasized the role of history and path dependence in the derivation of advantages, as well as the capabilities of entrepreneurial management in creating and leveraging cross-border resources, which are 
Valuable, Rare, Inimitable, and Non-substitutable (VRIN), and in co-creating markets and supporting business ecosystems (Pitelis \& Teece, 2010). Most of these ideas, but the most recent, were integrated in John Dunning's $(1980,2001)$ Ownership, Location, Internalization (OLI) framework, which also stressed the important role of location (Dunning \& Lundan, 2009).

A major limitation of the aforementioned theory of the MNE and FDI arises from its economics foundations and refers to its adherence to rational choice theory (Loasby, 2001)the idea that economic agents can select from a menu of existing alternatives, on the basis of their pre-existing preferences. Despite Hymer's richer insights as already cited, the very foundations of the theory of the MNE in Hymer are virtually a prototype or rational choice theory (with a menu of alternatives, such as FDI, licensing and co-operation, and the assumption of profit seeking by firms). The very concept of rational choice is predicated on the twin assumptions of a well-defined menu of existing (exogenous) alternatives and similarly exogenous preferences. Arguably, this limits the scope for anticipatory and proactive, purposive behavior, emphasized in entrepreneurship literature (Mises, 1949; Kirzner, 1973), and in behavioural business strategy (Gavetti, 2012). It ignores almost fully the role of the present as history (Zald, 1996) and hence it under-conceptualizes the question by whom and how the menu is created to start with.

The above is an important limitation in general, and specifically in the context of the resurgence of entrepreneurship scholarship (Alvarez \& Barney, 2007; Hoskisson, Covin, Volberda \& Johnson, 2011), the behavioral theory of strategy (Pitelis, 2007a; Gavetti, 2012) and the converging organizations and entrepreneurship scholars (Sørensen and Fassiotto, 2011). 
In contrast to the economics-based theories, International Management (IM) scholarship has emphasized process, induction, agency and history. Drawing on the classic work of Bartlett and Ghoshal (1989), management-oriented theories aimed to enter the 'black box' of the MNE and analyzed time honoured issues such as Integration/Responsiveness, entrepreneurship in subsidiaries (Hedlund, 1986; Birkinshaw \& Hood, 1998) and more recently ‘born global’ firms (Oviatt \& McDougall, 1994; Knight \& Cavusgil, 2004).

Drawing on both economics and IM-based theories, Doz (2004) has called for a managerial theory of the MNE that builds on the works of scholars such as Penrose (1959) and aims to be practice-based, marrying induction with deduction, content and process, agency and structure and the entrepreneurial managers' intra-firm view of management and organization scholars to the outsider-in firm-level perspective of economics-based views. He points to the need for a recognition of history and historical processes and in seeing managers as decision makers in context, as well as the need for multidisciplinary and eclecticism. He recognizes the difficulties involved and that extant attempts have not gone far enough. Knight and Cavusgil (2004) emphasised the need to bring together strategy, entrepreneurship and IB in order to explicate the nature of 'born global' firms. Hutzschenreuter, Pedersen and Volberda, (2007), moreover, integrate path dependent learning with managerial intentionality in order to explicate the process and paths of internationalization. These are all impressive contributions in the right direction.

With the exception of 'born global' thought, in IM, the analysis is limited to existing MNEs or their subsidiaries and does not address the fundamental issue and concern of IB, which is the nature of the MNE itself. In addition and despite the recognition by Doz of the importance of the context within which MNEs and managers operate, this is still largely taken as a datum (Doz, 2004). Last but not least, the demand side is basically ignored while 
the potential role of entrepreneurial imagination in helping explicate all these phenomena is absent.

\subsection{The Demand Side}

In recent years the Demand side perspective is gaining momentum in strategy and management scholarship. Adner and Zemsky (2006) have shown the importance of consumer demand and preferences in helping determine the SCA of firms. Priem, Butler and Li (2013) and Priem et al. (2012), have called for an analysis of value creation in firms, and the role of consumer demand in helping create and co-create value. As noted by Levitas (2013) the emergent demand-side approach emphasizes consumer value creation, consumer preferences and their dynamically changing nature. Levitas also notes that preferences can be partly endogenous and that instead of a new direction the demand-side view should be seen as an integrative part of a demand and supply side approach to management. Similarly Priem et al. (2012) call for an integrated value creation/value capture perspective. Pitelis (2009) stresses the co-determination of value capture, value creation and SCA pointing to the role of appropriability in incentivizing appropriable value creation.

The theory of the MNE as summarized above is supply-side driven and underplays the demand side of the equation. This limitation leaves the theory under-conceptualized and one-sided. Entrepreneurs and entrepreneurial managers venturing cross-border are likely both to be influenced by demand-side factors and aim to shape these to their advantage. These concepts are not fully alien to some early approaches to globalization and the MNE. Indicatively Vernon's (1966) product life-cycle theory, predicted that new products will first be introduced in developed markets with sophisticated consumers and then be introduced to developing countries when products mature, rivalry ensues, prices fall and (hence) demand conditions in new markets becomes more amenable. The idea that demand pressures at home 
can motivate outward investment also permeates many a textbook and case study of IB. The demand-side conditions in host markets are part and parcel of the 'locational' or countryspecific advantages in the OLI in the form of market side (GDP) and rate of growth of the market size (Hennart, 2009). Hymer's theory of risk diversification can be related to the overall risk of a country, including its business cycle hence demand. However, despite the above and the recognition of the importance of demand creation by MNEs in international marketing, these ideas only make indirect, guest-type appearances to the theory of the nature of the MNE and FDI, usually focusing on the integration/adaptation dilemma of extant MNEs (Theodosiou \& Leonidou, 2003).

Among the few studies to explicitly deal with the demand-side, Pitelis (1993) explored the role demand and supply-side conditions in developed countries played in engendering comparatively more attractive conditions for cross-border expansion. Pitelis (1996) tested the idea that aggregate demand is negatively related to outward investment in the UK, and found support for it, while more recently Kudina and Pitelis (2014) found econometric support for the idea that differential demand and business cycle conditions between developed and emerging economies can motivate outward investment into the latter.

Such studies remain few and far between and pale in insignificance as compared to the amount of scholarship spent on supply-side theories. In addition they focus on the role of demand (and the business cycle) in influencing FDI, not on how MNEs themselves try to impact on the demand and supply side cross-border, namely how to they try to shape the context within which they decide and function.

Below we build on the aforementioned contributions and aim to answer to the call by Doz (2004) for an integration between IB and IM and to the call by Priem et al. (2012) for an 
integrated value creation/value capture-informed theory, as applied to the case of crossborder expansion, the nature of the MNE and the context within which MNEs operate (that is cross-border organization), based on the concept of approriability-informed and legacyshaped entrepreneurial imagination. We complement extant demand-side approaches that focus on existing consumers and demand, by paying attention to demand and value creation though the extension, creation and co-creation of new markets, consumers and value.

\section{IMAGINATION, APPROPRIABILITY, AND CO-CREATION}

\subsection{Imagination}

The concise Oxford English Dictionary defines 'imagination' as “the faculty or function of forming ideas or mental images, the ability of the mind to be creative or resourceful". In Rycroft's Critical Dictionary of Psychoanalysis, 'imagination' is defined as "the process or faculty of conceiving representations of objects, events, etc., not actually present" (Rycroft, 1972).

'Imagination' is absent from the economics-based rational choice approach which assumes substantial (usually full and perfect) knowledge of present and future conditions. While useful for some purposes (for example as a benchmark against which to compare reality and for comparative static analysis), this approach is challenged in terms of its ability to analyze conditions characterized by limited or bounded, procedural rationality (Simon, 1947/1997; Cyert \& March, 1963) and learning (Nelson \& Winter, 1982; Argote \& MironSpektor, 2011). In such a world it could be argued that all approaches are 'behavioral', the question being which (imperfect) mechanism of choice is preferable for the problem in question (Knudsen \& Levinthal, 2007; Levinthal, 2011; Gavetti, 2012). As Loasby (2001) observed "Formal rationality plays a limited role in human cognition, which originated in the creation of patterns to interpret phenomena and link phenomena with action. The creation of 
new patterns rests on imagination, not logic, typically stimulated by a perceived inadequacy in established patterns" (Loasby, 2001, emphasis added).

As noted by Penrose (1955: 539), "[i]f the problems of adapting to rapidly changing external conditions are ignored, the simplest function of management is that of cocoordinating everyday operating activity within a given administrative framework, coping with minor problems, and improving existing ways of doing the same things." She goes on, however, that "[g]rowth requires initiative and imagination and thus a type of service different from that of the routine manager" (1955: 539, emphasis added).

In her 1959 book, Penrose (1959/2009) repeated similar ideas. For example, in comparing entrepreneurial to managerial or technical versatility, Penrose observed that:

"Entrepreneurial versatility is a somewhat different quality from management or technical versatility. The latter two qualities are primarily questions of administrative and technical competence; the former quality is a question of imagination and vision," (1959/2009: 32-33, emphasis added).

Shackle (1972) observed that to the extent entrepreneurs have any claim in being creators as opposed to mere receivers of history, this is due to their 'imagination' (p443). In Schumpeter (1954), the visionary stage is the central pre-analytic one in the process of construction of reality. The idea, if not always the word imagination itself, is frequently found in more popular explanations of corporate success. The strategy of the "visionary companies' in Collins and Porras's book Built to Last, for example, is shaped in part by a capability to pursue an "envisioned future", which "portrays a time yet unrealized - a dream, 
hope, or aspiration" (Collins \& Porras, 2002: 232). This is supported by Steve Jobs' dictum: "People don't know what they want until you show it to them. That's why I never rely on market research. Our task is to read things that are not yet on the page" (Isaacson, 2011: 567, emphasis added).

Such ideas have not been applied to the case of the nature of the MNE and cross-border business context co-creation, our focus here. Doing so is particularly important for conceptual but also for empirical reasons. The latter case is because cross-border expansion often involves existing firms with their legacies, and this legacy-shaped imagination can afford a more tractable context within which the concept of imagination can become more operationalisable. As noted by Doz (2004) such a need for operationalisability and delineation is a critical challenge for a managerial theory of the MNE.

\subsection{Appropriability}

Linking 'imagination' to the theory of the firm and the MNE requires a focus on the human agents who are the repositories of such imagination, for example in our case entrepreneurs and entrepreneurial managers. Drawing on Penrose, Witt (2007) identified entrepreneurship with 'the incessant (re)structuring of production and trade - be it via markets or via firms. For entrepreneurial ventures to be undertaken business opportunities must be imagined and conceptions for realizing them must be figured out in the first place. Visions like these are a crucial, though often overlooked, cognitive input to the entrepreneurial service of (re)organizing production and trade" (p. 1125-1126, emphasis added). 
It is arguable that the aim of entrepreneurs is to appropriate value from their perceived to be value creating advantages, actions, and action potential (Pitelis \& Teece, 2010). While broader than the economics focus on profit maximization, 'appropriability' remains a critical motivation for firms in market economies (Winter, 2006). It helps focus and delineate the scope of entrepreneurial imagination, that is, make it practicable. Such imagination is not aimed immediately at creating a better world, albeit such may (or may not) be an outcome. Instead, the aim of imaginative efforts here is to adapt, shape and help create the conditions that facilitate the objectives of the entrepreneurs, which typically involve the appropriation of as much value as possible from the value that entrepreneurial actions helped create, or cocreate.

Despite the large interest of literature on entrepreneurship in recent years (see for example Alvarez \& Barney, 2007; Hoskisson, Covin, Volberda \& Johnson, 2011 for surveys), often the emphasis is on 'value creation' (see for example Fayolle, 2007), at the expense of value appropriation. While well intentioned, such a focus misses the important point that in market economies it is often the case that appropriability concerns incentivize the very process of value creation and co-creations to start with (Pitelis, 2009). It is arguable that appropriability is the sine qua non of organizational strategy and entrepreneurship (Makadok \& Coff, 2002). What distinguishes private entrepreneurs from other value creating individuals, like philanthropists, is that their value creation and co-creation efforts are motivated by the desire to reap the fruits of these efforts, by appropriating as much as possible out of the created and co-created value in the form of profit. In this sense value creation and co-creation is aimed to be appropriable, hence informed by value appropriation. This is useful in that in its turn it helps to integrate value creation with value capture considerations (Priem et al., 2012), and helps delineate the type of imagined orders that entrepreneurs aim to create and co-create. 


\subsection{Co-creation}

In a world of limited and procedural rationality, uncertainty and change, there is a bound to what an individual entrepreneur can achieve on her own, no matter how imaginative versatile, ambitious and capable she is. While this may be particularly the case in new ventures facing resource constraints (Cornelissen \& Clarke, 2010), it is likely to be applicable in the case of cross-border expansion, not least because of the 'liability of foreignness' (Hymer 1960/1976; Zaheer, 1995). Appropriability in this context necessitates focusing one's capacities on mobilizing requisite human and non-human resources, capabilities, norms, attitudes, and institutions that help effect the desired objective. Absent perfect future markets, this usually involves the use of 'cognitive' leadership (Witt, 2007) for the creation and cocreation of an organization that can serve as a more potent vehicle for appropriability (Klein et al., 2010). This is because an organization involves the efforts of many; it can adopt strategies and structures designed for appropriability, and it can be granted (often endogenously, due to the efforts of entrepreneurs) by the state privileges, such as 'limited liability'. In their turn, organizations are in a better position to leverage their concentrated resources and capabilities, to create and co-create markets, networks, and business ecosystems that help them realize the objectives of their principals, the entrepreneurs.

In so doing, entrepreneurs have to target their imaginative efforts in order to picture opportunities for the creation and co-creation of markets, and business ecosystems, demand, consumer needs and institutions (Tolbert, David \& Sine, 2011). The way in which entrepreneurs try to create and legitimize new organizations, has been explored in institutional entrepreneurship literature (see for example Cornelissen \& Clarke, 2010). Our purpose here, instead, is to focus on the why and how of the far less explored issue of the creation and co-creation of the cross-border business context, namely the supply and demand- 
side conditions, and when feasible the wider socio-economico-political one, which firms will face when expanding cross-border. While firms have historically tried to do so too often with success in the past (Clegg, 2016), we acknowledge that with exceptions this may no longer be as easy today as it was in earlier eras of colonialism and 'banana republics'.

In particular, the success of the cross-border expansion is likely to be predicated on the creation and co-creation of new markets, hence demand, value and supporting business ecosystems. This is in part because of the 'liability of foreignness' (the fact that presence needs to be established in an unknown environment). It is also due to different conditions, the possible absence of home-based advantages and networks, and sometimes even markets and the surrounding business ecosystem. This comprises labour force (workers and managers in particular), suppliers, customers, complementors, the competitors of one's competitors, coopetitors, venture capitalists, and business angels, in all, everything that is taken for granted in more mature settings. As shown by the related literature on 'clusters', which are defined more broadly to include public, hybrid and academic organizations (Porter, 1990; Pitelis, 2012), the absence of a supporting environment can be a major barrier to SCA. When this is the case, the new market and business ecosystem needs to be created and co-created, so that SCA is being established.

\section{APPROPRIABILITY/LEGACY-SHAPED ENTREPRENEURIAL IMAGINATION IN HISTORCAL CONTEXT AND CROSS-BORDER ORGANIZATION}

The late nineteenth and early twentieth centuries saw the emergence and growth of modern industries and their diffusion as business enterprises crossed borders (Jones, 2005). They were primarily closely held or family businesses, led by larger than life entrepreneurial 
figures such as Henry Ford or Werner von Siemens. As a recent study of the emergence of the American airline industry argued, the start-up-phase is the moment when the role of the individual actor/entrepreneur is "vitally important," as they "allocate scarce resources, galvanize followers, and articulate a vision for a future state" (Mayo, Nohria \& Rennella, 2009: 17).

There are numerous cases when cross-border expansion was replete with visionary statements of their founders or early managers. For example, in 1924 Thomas J. Watson, the chief executive of the Computer-Tabulating-Recording Company, a modestly-sized manufacturer of a portfolio of small machines primarily sold in the domestic US market, renamed his company International Business Machines (IBM). Over the following three decades IBM evolved into a reality as it developed an international business and pioneered the computer age (McCraw, 2009). Of course identifying the imagination of Watson in this global growth of IBM is not to revert narrowly to a "great men" theory of history long held in disdain by professional historians. Entrepreneurs like Watson and their firms have relied on their own and their organizations' legacies and have imagined or re-imagined products, markets and business ecosystems, and acted upon their imaginative efforts in order to create and co-create reality, at home and cross-border with an eye to appropriating as much value as possible from the value co-created through their efforts.

The re-imagination of products and categories turns out to be a source of new market and demand creating appropriable advantage across a broad spectrum of industries. Blue jeans, for example, were working clothes in the US through to the 1960s. Then they were re-imagined as a more fashionable product, and then scaled cross-border. Firms such as Great Western Garment were key in the innovation of stone-washing, which enabled denim to achieve a larger and more versatile market. Categories, too, have been re-imagined. Here, 
the best example is green/environmental products. The growth of the "organic milk" market in Sweden has been explained by business historians using corporate archives in terms of social construction, or imagination (Broberg, 2010). Indeed all sorts of interlinked actors get involved in the process - including certification bodies, who in turn act internationally. The autobiographies of prominent green entrepreneurs are replete with references to the importance of imagination. Tom Chappell, the founder of the highly successful Tom of Maine's personal care brand in the 1970s, emphasized the importance of "creative imagination" in entrepreneurial success in his autobiography, as well as the importance of management styles which "open(ed) up and honor the minds and imaginations of your employees" (Chappell, 1993).

While both entrepreneurs and organizations are, in a general sense, products of their history, the substantiation of the link between history and imagination requires appropriate context. While 'imagination' can be unreal and/or unrealizable (or impractical), the aim of appropriability-legacy-informed 'imagination' is delineated by the need to act upon what is imagined in order to realize it and in a way that permits appropriability. In this context, it is arguable that imaginative efforts will draw on extant experiences, learning and insights. If so, entrepreneurs who have visualized what is possible in some contexts, e.g. countries, may well ‘imagine' a situation where similar, suitably modified, appropriately adapted conditions, can be created and co-created in other contexts, at home and/or in foreign countries, i.e. crossborder. To the extent this involves drawing on available experience in a home country and tries to shape the context in a host country, the choice of cross-border affords a higher degree of operationalisability. Similarly however operationalisability becomes more feasible when one looks at advantages downstream to the level of the entrepreneur, as opposed to the level of the firm. In such cases entrepreneurs can perceive desired realities drawing on their experiences, knowledge, learning, intentionality and appropriability-informed imagination 
that motivate decisions and actions that help create and co-create a desired context for their planned operations at home and cross-border.

There exist various ways in which legacy-informed imagination can help existing companies to shape cross-border context. One involves shaping cross-border to one's home country image. This is the Hymerian view, akin to what Doz (2004) calls replication. A variant involves entrepreneurial managers imagining organizational, industrial and institutional structures cross-border that might have been possible, but are not (or no longer) available in their home markets. These may relate to impacting on market structures (for example, less competition cross-border and/or possibility of reducing the forces of competition), regulatory, trade, and institutional regimes. Regulation policy, for example, may be more (or less) lax, trade policy may be more (or less) protectionist, appropriability regimes, stronger or weaker. Institutional arrangements may be more (or less) conducive to entrepreneurship and "doing business", gaps to be filled, and other opportunities may be more numerous. In such cases, entrepreneurs can visualize possible structures cross-border, more amenable to the realization of their objectives.

In some cases, opportunities such as the above can draw on past experiences at home, and the resultant learning through trial and error. Errors, however, may not always be correctable within a country, due to irreversibility and path dependencies. Cross-border expansion provides a new terrain where past errors can be avoided, in a fresh new setting. Cross-border in such cases could provide opportunities to 'rectify' past mistakes, to use, so to speak, a second opportunity. In such cases, cross-border differences, whether extant, or possible to engender, can be perceived as conventional 'locational advantages' and/ or opportunities. This type of 'error correction-based' reasoning adds an interesting twist to the Hymerian approach, in that it views the future as hitherto unrealized history. 
The aforementioned ideas become clearer when one looks at some illustrative case examples. Take for example the case of McDonald's expansion to Russia. This effectively involved the co-creation of a market and business ecosystem, which was aimed to eventually serve the preferred model of McDonald's to franchise, as stated explicitly by the company's top management (Pitelis \& Teece, 2010). McDonald's observed a situation without potential franchisees. It imagined and then put in place a process of facilitation of small business creation, with an eye to eventually turn them into franchisees. It helped co-create organizations, a new market and a supporting ecosystem, with an eye to this eventually serving the model that had served it well in other markets. It imagined a new situation, based on its knowledge of the existing situation in its core markets, and proceeded to create the conditions that would allow it to appropriate value from the value it helped co-create, by leveraging its already tested business model.

There is also ample historical evidence concerning the correction of past errors by firms. That was prominent in the early history of one of the world's first manufacturing multinationals, the US-based Singer Sewing Machine Company. The corporate archives of this company are publicly available and have been employed in many scholarly studies by business historians. During the early 1850s Edward Clark began a series of marketing and other innovations, which grew the firm's position in its domestic market, and he had a vision of strong international expansion. In 1854 he licensed the firm's technology to a French company. This appeared a low cost way to access international markets, but soon encountered the now familiar issues related to transactions costs as the French company allegedly cheated and failed to invest in production. In 1867, when Clark began international expansion after the end of the US Civil War, he opted for greenfield investment in a new factory in Scotland. Singer never licensed its technology again. (Carstensen, 1984; Godley 1999). 
Our discussion and illustrative case examples lead to our baseline propositions/trajectories (hereafter PT) 1 and 1a.

PT1. Established firms venturing cross-border will draw on their home experiences/legacy to create conditions that help them realise previously experienced opportunities.

PTla. Established firms venturing cross-border will draw on their home experiences/legacy to create conditions that help them 'correct' past errors in host countries.

The case of Jardine Matheson \& Company (JMC) supports Proposition 1a further. A 200-year old trading company based in Hong Kong and ultimately owned by a British family, JMC evolved to become a successful MNE by shaping the legal environment for business and trade in China in a way that suited its interests and could no longer be achieved at home (Connell, 2006). Infamously that involved lobbying the British government hard to wage the first Opium War with China, over attempts by the latter to curb imports of the drug by the company and other importers. In an article entitled 'Return to China', The Economist (2015) observes Jardine's ability to navigate successfully the economic nationalism in Indonesia and its recent deals in/return to China, and concurs that Jardine's long history is more an asset than a liability, not least in that "They don't make the same mistake twice".

Much like the East India Company, Jardine Matheson helps explain the very emergence of the institutions that are regarded in conventional theory as the repositors of firm-specific advantages and capabilities, and the identifiers of efficiency and controlenhancing modalities. These, we pointed out, might not have ever existed in the absence of appropriability-informed, legacy-shaped entrepreneurial imaginings and actions. As noted, cases such as these and the East India Company are likely to be less common in today's post- 
colonial settings, which explains our main focus on the business context as opposed to the wider context in this paper. It is noted however that even in the case of McDonald's and similar cases, attempts to influence the wider socio-political and institutional context still abound (Clegg, 2016).

While the case of established firms involves firm-specific advantages in line with conventional theory, in other cases FSAs do not exist, with the advantage lying downstream at the level of the entrepreneur. Take for example the case of mobile banking. The mobile banking revolution in Kenya is a case of appropriability-informed entrepreneurial imagination that identified/created an opportunity because of a disadvantage/problem, that is the absence of conditions that facilitate conventional banking (Perry \& Wadhams, 2011). The new business model, based on the use of mobile phones, has helped create a totally new market hence demand and value. It has also helped engender a new cross-border scalable market and demand for banking products. The knowledge created through the realization of a "vision" by an entrepreneur in Kenya (Michael Joseph of Safaricom) was predicated on locational and organizational challenges and disadvantages, not advantages. It is now being transferred all over the world (Joseph served as a World Bank Fellow, advising also mature economists). The emergent company (Safaricom) had to develop cross-border experience and capabilities, by collaborating with Vodafone, namely cross-border expansion through cooperation. An outcome is FDI by Vodafone in Kenya, which, however, resulted from the imagination, and (cognitive) leadership of the Kenyan entrepreneur, which was triggered by challenges faced in their markets and led to the creation of a new market, demand and supply (first local then cross-border) of the newly demanded products. In the above case it is problems or challenges that help engender innovative solutions that involve both supply side (organizational) and demand-side (market creation) dimensions. The problems and solutions are the outcome of appropriability-motivated entrepreneurial 'productive opportunity', co- 
created through the combination of legacy-based knowledge and learning, alongside the external challenges.

This leads to our second proposition/trajectory.

PT2. Entrepreneurs facing scarcities/challenges at home can leverage their individual advantages in their home countries to devise problemistic search-derived innovations/ business models and activities that can create new potentially cross-border scalable markets

It is arguable that the concept of 'jugaad innovation' (Radjou, Prabhu \& Ahuja, 2012) is often linked to such disadvantages/challenges. This 'challenge-triggered' entrepreneurial imagination and action is akin to Cyert and March's (1963) 'problemistic search', but applied downstream to the level of the entrepreneur, not the firm. It turns on its head the conventional approach to the MNE, which requires FSAs, as opposed to entrepreneurial advantages which application is triggered by organizational and country-wide challenges and disadvantages. It is in line with the literature on 'born global' firms that also emphasizes the role of scarcity and challenges that can lead to innovative solutions aimed to early stage internationalization (Oviatt and McDougall, 1994; Knight and Cavusgil, 2004). While mostly applied to the supply-side in extant literature on 'born globals', such actions also help explain market and demand-side creation. Indeed, mobile banking is all about the creation and then co-creation of new market, consumers' demand and appropriable value.

A third type of entrepreneurial perception and imagination in practice refers to opportunities, resources and conditions only available abroad, and/or in a co-specialized fashion. These include the subset of conventional locational advantages, which are only present cross-border. It also includes co-specialised and complementary assets, which only 
exist in other counties and differentially favourable demand conditions abroad. We call this cross-border 'opportunity-driven' entrepreneurial action. This is in line with Cyert and March's 'slack-induced innovation', Dunning's 'strategic asset seeking' and Hennart's (2009) asset bundling, extended to the demand-side too and applied to the case of the entrepreneur.. This is particularly relevant for the case of 'born globals', and highlights the role of managerial intentionality, not merely path dependent learning (Hutzschenreuter et al., 2007).

An illustrative case example is that of Rolex. The emergence of wristwatches, especially luxury wristwatches, provides a telling example of how legacy-informed entrepreneurial imagination can help engender a 'born global' firm, even when there exist no appreciable FSAs, but there exists cross-border co-specialization of assets and/or differentially favourable demand conditions.

Watches emerged in the sixteenth century. However, they were pocket and purse watches, not wristwatches. The first wristwatches were considered a passing fad. In 1868 the Swiss watchmaker Patek Philippe made a wristwatch for women, but few were sold, and they remained marginal, perceived as inaccurate, and mostly targeted at upper-class women who did not have business appointments to keep. Manufacturers made watches and sold them to retailers who branded them.

It was the founder of Rolex, Hans Wilsdorf, a German who established a watch company in London before World War I, who re-imagined wristwatches as reliable and accurate watches, sold at a premium price, often to men. Unlike Singer, the historical archives of Rolex appear to be wholly inaccessible. The following reconstruction of the 
firm's history, therefore, relies on two unconventional sources, a substantive but "unauthorized" history of the firm (Brozek, 2002), and a Harvard Business School case study. (Jones \& Atzberger, 2013).

The execution of Wilsdorf's vision involved major innovations in manufacturing strategy and branding. First, Wilsdorf integrated retailing and manufacturing under his own control with the aim of achieving the highest quality of production. Before 1914 he signed a large supply contract with a producer of precise, small, and reliable watch movements in Switzerland, and bought the supplier some years later. Second, he sought external validation of extreme quality. In 1910 he sent one of his watches to the School of Horology in Bienne, Switzerland. It became the first wristwatch to receive a chronometer rating. Subsequent watches were tested at the prestigious Kew Observatory outside London, which had previously only tested marine chronometers that required exceptional standards of accuracy. By 1927, 92\% of all watches tested in the "Official Swiss Institute for Testing the Timekeeping of Watches" were Rolex watches. Third, Wilsdorf engaged in luxury brand building. Wilsdorf invented the name Rolex, apparently while riding on the top deck of a bus in London. This was a remarkable departure from other watch companies or retailers, which used their family names to describe their watches, but more interestingly the name meant nothing at all, providing an aura of mystique. The word Rolex was registered in Switzerland in 1908 and in London in 1912. Wilsdorf then started branding his watches, not selling them to retailers. After relocating to Switzerland due to anti-German sentiment in World War I, Wilsdorf began marketing his watches by linking them to extreme sports. In 1927 Rolex sponsored Mercedes Gleitz, a pioneering female swimmer to cross the English Channel, wearing the Oyster watch. No water had entered the watch when she exited the water on the other side of the English Channel, an achievement that Rolex advertised on the front page of London's Daily Mail. In 1930, Wilsdorf sponsored the Swiss water polo team. The use of 
extreme athletes to advertise became a hallmark of Rolex marketing (Brozek, 2002; Jones \& Atzberger, 2013).

In short, Rolex's Wilsdorf took a product, which was sold as a trinket to rich women, and turned it into an expensive luxury branded product sold often to men. This was done by a combination of an emphasis on quality, the building of aspirational emotional associations for the brand, and exploitation of London locational (market/demand-side) advantages first, and country of origin (reputation and co-specialisation) effects associated with Switzerland later. During the 1920s the firm grew as a MNE by growing from its Swiss and British bases by creating international sales subsidiaries, and in the early 1930s opened a subsidiary in the United States (Brozek, 2002; Jones \& Atzberger, 2013).

Wilsdorf imagined and then created and co-created and legitimized (Aldrich \& Fiol, 1994) the wrist watch sector, leveraging locational advantages of two countries simultaneously, and was, in effect, a 'born global' (or at least cross-border), by exploiting cospecialized assets and capabilities and differential demand conditions between the UK and Switzerland. Considering that there were no initial appreciable "ownership or monopolistic advantages" to be subsequently internalized, this case, too, is hard to reconcile with traditional theory of MNE. Instead, we have a 'born global' firm that leveraged dual locational (supply and demand-side) advantages and asset co-specialization, driven by the imagination and actions of an appropriability-informed entrepreneurial genius. These imaginations and actions however depended on prior knowledge of both the market and the locational advantages of two countries; they were legacy-based and shaped. Wrist watches therefore were the result of opportunity-driven actions, based on the legacy and knowledge of its founder. This is in line with Proposition/Trajectory 3. Moreover, Rolex was a 'born global' company. This was because of co-specialised assets in two different countries - skills 
and capabilities for production in Switzerland and favourable demand by an emerging middle class in the UK.

The above analysis and illustrative example leads to our third proposition/trajectory.

PT3. Co-specialized resources and capabilities an/or differentially favourable demand conditions cross-border, will motivate entrepreneurs to set up 'born globals' firms

The lack of ownership/firm specific advantages (FSAs) here too, renders the Rolex case hard to explain in terms of conventional theory. This is not because of the absence of advantages per se but rather because the advantages in this case are downstream to the entrepreneur, not the firm itself. The advantages are ones of appropriability-informed imagination, intentionality, decision-making and commitment. In this sense the case of Rolex supports but also complements literature on 'born globals'. While impressive, this literature sometimes fails to distinguish between cross-border presence (e.g., through exports) and the 'nature' of the MNE, which in more conventional literature requires FDI. In Rolex we have a 'born global' with FDI. There are other such cases (see Pitelis and Teece, 2010), in most of which co-specialization plays a critical role. Bringing in co-specialization helps complement and support the 'born global' literature.

In summary, we claimed that the legacy-informed and shaped creation and co-creation of cross-border markets, demand and business ecosystems, hence value, for the purposes of appropriation by entrepreneurs, can serve be a potent reason for cross-border expansion, the existence of the MNE and cross-border business organization. In our context, the choice of FDI (the MNE), as opposed to licensing, for example, is predicated on the fact that the realization of one's imagined reality is facilitated by the power to do so, which in its turn is 
likely to be higher in the case of an organization with presence on the ground, hence the ability to shape and influence the environment, more than through a licensee. Unlike the case of Hymer, this need not be monopolistic power, aimed at reducing rivalry. In the cases we refer to, 'rivals' can often be absent and even need to be invented, or created! We refer instead to positive creative power, power to shape, create and co-create new supply and demand-side realities (Foucault, 1980).

Our analysis helps provide a context within which extant theories are constructed and co-constructed by legacy-appropriability-informed purposive, mostly entrepreneurial action. The choice theoretic framework can be valuable when choices are present and known, but less so in environments and cases where these need to be created and co-created to start with. Within such contexts, transaction costs and other superior efficiency-related arguments are important, more like the means rather than the cause and in explicating the choice of modalities, as opposed to the creation of the context within such choices are taken. The last mentioned, we suggest, is often legacy-shaped, history-informed imaginative entrepreneurs and entrepreneurial managers.

We have submitted that appropriability-informed and legacy-shaped entrepreneurial imagination that aims to mirror image extant experiences at home and/or correct past errors, address organizational and locational disadvantages and challenges and take advantage of exclusively cross-border available and/or co-specialised supply and demand-side opportunities, that leverages organizational power for the purpose of cross-border market, demand and business ecosystem creation and co-creation, is a potent alternative to (indeed an encompassing framework of) extant 'internalization' theory. In our perspective managers 'internalize', whereas entrepreneurs do much more: they 'imagine' and act on their images and visions to create a world that helps them realize their dreams by amassing and leveraging 
all power they can get to do so. This often involves the setting up of (often state sanctioned) organizations, the leading of people, the influence of policy makers, and the development of requisite capabilities to achieve those.

Figure 1 summarizes our main arguments. In its context, legacy-appropriabilityinformed, entrepreneurial imagination (Box1) leads to market, demand and business ecosystem co-creation (the business context) at home (Box2). Emergent scalable cross-border FSAs but also downstream entrepreneurial advantages motivate cross-border expansion of three major types/trajectories (Boxes 3, 4 and 5) that are intended to help shape and co-create the cross-border business context (Box 6). Modalities (Box7), and (hence in the case of FDI the nature of the MNE, are predicated on perceived cross-border co-specialization of assets, as well as to the partly endogenous to entrepreneurial/firm actions transaction costs, rivalry reduction and resources/capabilities considerations of extant cross-border modality theories. The choice of location (Box 8) is partly endogenous and predicated on asset co-specialisation but also perceived capability in shaping the business environment through local presence on the ground (which in turn also favours the FDI modality that affords more control). This helps endogenise advantages, modalities and location, the three parts of the OLI triad (Pitelis, 2007b). The arrows show the direction/path of the process but not the co-determination, coevolution and feedback loops. This is because our focus is on causal pathways and less on the latter - which is a future research opportunity. For example, while Box1 leads to Box2, this is with an eye to influencing the choice of modalities (Box 7) and with location (Box 8) being chosen endogenously. Entrepreneurial advantages and FSAs as applicable lead to the three cross-border paths/trajectories (Boxes 3, 4 and 5) which in turn lead/shape the cross-border business context (Box 6), again with the modalities choice in mind and with location being at least in part endogenous (albeit not shown in the figure with arrows for the reasons explained). In our simplified version, Box 1 causes Box 2 at home, as well as boxes 3 , and 5 
cross-border, Box 2 at home causes Box 4 cross-border and the three cross-border boxes/trajectories cause the next cross-border Box 6, that of the cross-border context. Examples and propositions/trajectories (PTs) are also included in the boxes. It is important to note that conventional FSA-based theory cannot not account for direct arrows from Box 1 to the two PT boxes (3 and 5) suggested by our approach, as Box 2 (a pre-existing firm) is a presupposition for FSAs and cross-border expansion. Of course Box 2 can also lead to Boxes 3 and 5 (also not shown in Figure for simplicity).

Our approach can explain more readily market and demand creation and co-creation, 'born globals' and MNEs even in cases of organisational and country-specific disadvantages, (e.g. the case of Kenyan mobiles). In the case of MNEs from emerging countries, problemistic search-driven business model innovation is widely perceived to be an important way through which such companies compete. The case of MNEs that arise from 'firm and country-specific dis-advantages' challenges conventional IB theory that relies on FSAs instead. In our framework advantages are still present but often downstream, in the appropriability-shaped entrepreneurial imagination.

In the case of 'born globals' (Oviatt and McDougall, 1994), the role of co-specialised assets that are exclusively available in two or more different countries has received limited attention. This is in part because much of the literature on 'born globals' focuses on crossborder expansion in general, including exports, as opposed to cross-border FDI (hence the nature of MNE in the more conventional IB literature). In this context the case of 'born global' MNEs (ie born globals with FDI) is very interesting, yet arguably underconceptualised subset of 'born globals'. Bringing co-specialization as envisaged/imagined by entrepreneurs into the 'born global' literature helps extend and support the latter's contribution to issue of the nature of the MNE. 


\section{DISCUSSION, LIMITATIONS AND CONCLUDING REMARKS}

While the example of McDonald's in Russia and those of Singer and Jardine Matheson, involve FSAs, Kenya's mobile banking shows how entrepreneurial imagination/advantages alongside country-specific and organizational challenges/disadvantages can serve to create new markets and launch innovative business models, which are scalable cross-border. Cases like Rolex, moreover, illustrate how traditional FSA-based theory can be found wanting in explicating 'born globals', which lack such advantages, but where the advantage lies with the entrepreneurial imagination and appreciation of the importance and role of cross-border asset co-specialisation and differential demand conditions.

In all case examples described, legacy-shaped, appropriability-informed entrepreneurial imagination and supporting actions are seen to play a critical role in the creation and co-creation of organizations, markets, demand and business ecosystems, hence new value at home and cross-border. This helps explain the very emergence of the conditions that are regarded in conventional theory as the repositories of firm and country-specific advantages and capabilities, and the identifiers of efficiency and control-enhancing modalities. These, we pointed out, would not have ever existed, in the absence of appropriability-legacy-informed entrepreneurial imaginings and actions. The last mentioned, we submit, should be placed centre stage in any explanations of cross-border activities, FDI and the MNE. Being entrepreneurial-agency-based, this approach helps explicate better 'born globals' without apparent organizational (as opposed to just entrepreneurial) advantages, such 
as Rolex (a phenomenon conventional theory has trouble in explaining), as well as the codetermination, co-evolution and co-adaptation of organizations, markets, business ecosystems, institutions, and thereby the shaping of choice, including the choice of modalities, which can itself be partly endogenous (as in the example of McDonald's).

In summary, in our framework, appropriability-informed, legacy-shaped imagination by entrepreneurs can serve as a more appropriate heuristic to rational choice theory, for the explanation of the nature of organizations, markets and modalities, including FDI and the MNE, without however doing away with it-thereby answering to Doz's clarion call. Entrepreneurs envision new patterns (markets and business ecosystems) and act upon their images to realize their dreams for personal gain (notably, but not exclusively, appropriation of returns in the form of profit). In a world of bounded rationality, uncertainty and change, but also learning and un-learning/managerial intentionality, the power to effect imagined desired outcome is of the utmost importance. Organization facilitates the realization of imagined outcomes. Organization co-creation in particular helps shape and co-creates supply and demand-side conditions, notably markets, business ecosystems and even institutions that allow ambitious and versatile entrepreneurs to turn imagination to reality. Power and legitimization mediate between imagination and realization. Cross-border scalability, cospecialization and differential demand conditions help explicate cross-border expansion through FDI, thus the MNE, including 'born globals'. Transaction costs reductions and superior capabilities-based arguments can more appropriately be seen as more static choicetheoretic constructs, more useful to managers than entrepreneurs. Being historical, entrepreneurial-agency-based, this approach helps explicate 'born globals', such as Rolex, and cases of MNEs emerging out of entrepreneurial advantages and actions triggered by scarcity and country-specific disadvantages, such as Kenyan mobiles. 
The illustrative case examples discussed in the previous section are but a small subset from a wealth of historical literature that helps demonstrate the need to leverage the concepts of legacy-appropriability-informed entrepreneurial imagination and actions, and explore its implications for a better appreciation of supply and demand-side, value creation and value capture-based theory of cross-border expansion, the MNE and cross-border organization.

The view that "history matters" has become quite widespread in the IB and IM literatures (Doz, 2004; Jones \& Khanna, 2006; Buckley, 2009). However the issues of how it matters, and how historical scholarship can be incorporated into the IB and management literature remain unresolved. It is evident that 'history' is more than the assembly of longitudinal data and other empirical evidence about the past, important as that is in correcting fallacious assumptions about how the world worked before the present day. Historians also employ a different methodology than social scientific- informed research. As one recent important study has argued, "historical reasoning" highlights the temporal location of particular decisions in analyses where sequence and context are crucial, and it helps establish the interdependency of variables over time, or in other words, the variation in causal relationships between independent and dependent variables can change over time (Bucheli \& Wadhwani, 2014). In this context, and as noted by Penrose, history should inform good theory and big data-based quantitative/econometric analysis, while on the other side without a good history-informed theory, history itself can become a series of unconnected, even unappreciated occurrences.

The present authors understand, then, that the nature of the evidence used below represents only snapshots of historical episodes. As in Jones and Khanna (2006) they explicitly draw on often meticulously researched secondary sources. They do not represent primary historical research, but rather seek to illustrate points based on existing rich 
secondary literature re-imagined to support theory development and however limited operationalisation on the elusive concept of entrepreneurial imagination. The complex nature of historical evidence noted above means that in this context these examples are offered to open up a debate, rather than to be a definitive account. However, we submit that they remain useful in challenging extant views and in helping develop better theory. Clearly, more can be done on both fronts.

There is scope for more research on this new line of thought that we plan to pursue, and hope others will too. Such research (and a limitation of our paper so far) could involve cases of chronic business failure. There may well be more trajectories, not identified in our framework. In addition, it is important to develop insights on the potential co-determination and co-evolution of informed imaginings, visions, modified, realized ones, based on the interaction of internal and external forces, as well as serendipitous factors. These represent an exciting research agenda. For our purposes here, we submit that a better understanding of international business organization requires history and agency, notably the entrepreneur, to be placed center stage. The analysis of appropriability-informed and legacy-shaped entrepreneurial imagination and supporting actions can then help provide a dynamic framework that helps explain both the demand and supply-side, that foster appropriable value creation through the creation and co-creation of the business (and when possible wider) context of cross-border organization, markets, business ecosystems and modalities, and place suitably adapted conventional analysis, within its remit.

\section{REFERENCES}

Adner, R., \& Zemsky, P. (2006). A demand-based perspective on sustainable competitive advantage. Strategic Management Journal, 27(3): 215-239. 
Aldrich, H. E. \& Fiol, C.M. 1994. Fools rush in? The institutional context of industry creation. Academy of Management Review, 19(4): 645-670.

Alvarez, S. A. \& Barney, J. B. 2007. Discovery and creation: alternative theories of entrepreneurial action. Strategic Entrepreneurship Journal, 1: 11-26.

Amabile, T.M (1996). Creativity in Context. Boulder, CO: Westview.

Argote, L. \& Miron-Spektor, E. 2011. Organizational learning: from experience to knowledge. Organization Science, 22(5): 1123-1137.

Bhidé, A. V. 2000. The origin and evolution of new businesses. Oxford: Oxford University Press.

Birkinshaw, J., \& Hood, N. (1998). Multinational subsidiary evolution: capability and charter change in foreign-owned subsidiary companies.Academy of Management Review, 23(4): 773-795.

Bartlett C. \& Ghoshal S. 1989 Managing across borders: the transnational solution, London: Century Business

Boulding, K. 1956. The image: knowledge in life and society. Michigan: University of Michigan Press.

Broberg, O. 2010. Labelling the good: alternative visions and organic branding in Sweden in the late twentieth century. Enterprise \& Society, 11(4): 811-838.

Brozek, J.E. 2002. The Rolex report. An unauthorized reference source for the Rolex enthusiast. St. Petersburg, L1.: InfoQuest Publishing.

Bucheli, M. \& Wadhwani, R.D., Eds. 2014. Organizations in time. History, theory, methods. Oxford: Oxford University Press.

Buckley, P. J. 2009. Business history and international business. Business History, 51 (3) : 307-333.

Buckley, P. J. 2010. The theory of international business pre-Hymer. Journal of World Business, 46(1): 61-73. 
Buckley, P. J. \& Casson, M.C. 1976. The future of multinational enterprise. London: Macmillan.

Cantwell, J. A. 1989. Technological innovation and multinational corporations. Oxford: Basil Blackwell.

Carstensen, F.V. 1984 American enterprise in foreign markets. Chapel Hill: University of North Carolina Press.

Casson, M.C. 1982. The entrepreneur: An economic theory. Oxford: Martin Roberston.

Casson, M.C. 1986. General theories of the multinational enterprise: their relevance to business history. In P. Hertner \& G. Jones (Eds.), Multinationals: Theory and history: 42-63. Aldershot: Gower. .

Casson, M. C. 1995. Entrepreneurship and business culture. Aldershot: Edward Elgar.

Chappell, T. 1993. The soul of a business. New York: Bantam.

Clegg, S. 2016. The East India Company: The first modern multinational? In C. Dörrenbächer and M. Geppert (Eds.), Multinational Corporations and Organization Theory: Post Millennium Perspectives. Research in the Sociology of Organizations, Bingley: Emerald Publishing.

Collins, J. \& Porras, J.I. 2002. Built to last. Successful habits of visionary companies. New York: Collins.

Connell, C. M. 2006. Entrepreneurial enterprise and 'image' in the nineteenth-century trading firm: shaping the legal environment for business. Business History, 48(20): 193-219.

Cornelissen, J. P. \& Clarke, J.S. 2010. Imagining and rationalizing opportunities: inductive reasoning and the creation and justification of new ventures. Academy of Management Review, 35(4): 539-557.

Cyert, R. M. \& March, J.G. 1963. A behavioral theory of the firm. Englewood Cliffs, NJ: Prentice Hall. 
Doz, Y. L. (2004). Toward a Managerial Theory of the MNC. Advances in International Management, 16: 3-30.

Dunning, J. H. 1980. Toward an eclectic theory of international production: some empirical tests. Journal of International Business Studies, 11(1): 9-31.

Dunning, J. H. 2001. The eclectic (OLI) paradigm of international production: past, present and future. International Journal of the Economics of Business, 8(2): 173-190.

Dunning, J. H. \& Lundan, S. M. 2009. The MNE as a creator, fashioner and respondent to institutional change. In S. Collinson \& G. Morgan (Eds.), The Multinational Firm: 93115. Oxford: Blackwell.

Dunning, J. H. \& Pitelis, C.N. 2008. Stephen Hymer's contribution to international business scholarship: an assessment and extension. Journal of International Business Studies, 39(1): 167-176.

The Economist, 2015. Jardine Matheson. Return to China. The Economist, July 4, 57.

Einstein, A. 1931. Cosmic religion and other opinions and aphorisms. New York: CoviciFriede.

Fayolle, A. 2007. Entrepreneurship and new value creation: The dynamic of the entrepreneurial process. Cambridge: Cambridge University Press.

Foucault, M. 1980. Power/knowledge: selected interviews and other writings by Michel Foucault, 1972-77. (C.Gordon, ed.). Brighton: Harvester.

Gavetti, G. 2012. Toward a behavioral theory of strategy. Organization Science, 23(1): 267285.

Godley, A. 1999. Pioneering foreign direct in British manufacturing. Business History Review, 73: 394-429

Hamel, G. and Prahalad, C.K. (1991) Corporate Imagination and Expeditionary Marketing, Harvard Business Review, July-August: 2-11. 
Hedlund, G. 1986. The hypermodern MNC-A heterarchy?.Human Resource Management, 25(1): 9-35.

Hennart, J. F. 1982. A theory of Multinational Enterprise. Ann Arbor, Michigan: University of Michigan Press.

Hennart, J. F. 2009. Down with MNE-centric theories! Market entry and expansion as the bundling of MNE and local assets. Journal of International Business Studies, 40(9): 1432-1454.

Hoskisson, R.E., Covin, J., Volberda H. \& Johnson, R.A. 2011. Revitalizing entrepreneurship: the search for new research opportunities,' Journal of Management Studies, 48(6): 1141-1168.

Hutzschenreuter, T., Pedersen, T., \& Volberda, H. W. (2007). The role of path dependency and managerial intentionality: a perspective on international business research. Journal of International Business Studies, 38(7): 1055-1068.

Hymer, S. H. 1960/1976. The international operations of national firms: a study of foreign direct investment. Cambridge, MA: MIT Press.

Hymer, S. H. 1972. The multinational corporation and the law of uneven development. In J. N. Bhagwati (Ed.), Economics and world order: 113-140. London: Macmillan.

Isaacson, W. 2011. Steve Jobs. New York: Simon and Schuster.

Johanson, J. \& Vahlne, J.E. 2009. The Uppsala internationalization model revisited: from liability of foreignness to liability of outsidership. Journal of International Business Studies, 40(9): 1411-1433.

Jones, G. 2005. Multinationals and global capitalism. Oxford: Oxford University Press.

Jones, G. \& Atzberger, A. 2013. Hans Wilsdorf and Rolex. Case 9-805-138. Boston, MA: Harvard Business School Case Services.

Jones, G. \& Khanna, T. 2006. Bringing history (back) into international business. Journal of International Business Studies, 37(4): 453-468. 
Kirzner, I.M. 1973. Competition and entrepreneurship. Chicago: University of Chicago Press.

Klein, P. G., Mahoney, J. T., McGahan, A. M. \& Pitelis, C.N. 2010. Toward a theory of public entrepreneurship. European Management Review, 7(1): 1-15.

Knight, G. A., \& Cavusgil, S. T. (2004). Innovation, organizational capabilities, and the bornglobal firm. Journal of International Business Studies, 35(2): 124-141.

Knudsen, T. \& Levinthal, D.A. 2007. Two faces of search: alternative generation and alternative evaluation. Organization Science, 18(1): 39-54.

Kogut, B. \& Zander, U. 1993. Knowledge of the firm and the evolutionary theory of the multinational corporation. Journal of International Business Studies, 24(4): 625-645.

Kudina, A., \& Pitelis, C. 2014. De-industrialisation, comparative economic performance and FDI inflows in emerging economies. International Business Review, 23 (5): 887-896.

Levinthal, D. 2011. A behavioral approach to strategy - what's the alternative? Strategic Management Journal, 32(13): 1517-1523.

Levitas, E. (2013). Demand-Side Research's Role in Macro-Management A Commentary on Priem, Li, and Carr. Journal of Management, 39(5): 1069-1084.

Loasby, B. J. 2001. Cognition, imagination and institutions in demand creation. Journal of Evolutionary Economics, 11(1): 7-21.

Makadok, R. \& Coff, R. 2002. The theory of value and the value of theory: breaking new ground versus reinventing the wheel. Academy of Management Review, 27(1): 10-13.

Mayo, A.J., Nohria, N. \& Rennella, M. 2009. Entrepreneurs, managers, and leaders. New York: Palgrave MacMillan.

McCraw, T. K. 2009. American business since 1920. How it worked. Wheeling, IL: Harlan Davidson.

Mises, L.V. 1949. Human action: a treatise on economics. New Haven, CT: Yale University Press. 
Nelson, R.R. \& Winter, S.G. 1982. An evolutionary theory of economic change. Cambridge, MA: Belknap Press.

Osburn, H. K. and Mumford, M.D (2006). Creativity and Planning: Training Interventions to Develop Creative Problem Solving Skills. Creativity Research Journal18(2): 73-90.

Oviatt, B. \& McDougall, P. 1994. Toward a theory of international new ventures. Journal of International Business Studies, 25(1): 45-64.

Papanastassiou, M. \& Pearce, R. 2009. The strategic development of Multinationals: Subsidiaries and innovation. London: Palgrave MacMillan.

Penrose, E. T. 1955. Limits to the growth and size of firms. American Economic Review, 45(2): 531-543.

Penrose, E. T. 1959/2009. The theory of the growth of the firm ( $4^{\text {th }}$ ed.). Oxford: Oxford University Press: Oxford.

Penrose, E.T. 1989. History, the social sciences and economic theory with special reference to multinational enterprise. In A. Teichova, M. Levy-Leboyer \& H. Nussbaum (Eds.), Multinational Enterprise in Historical Perspective: 7-14. Cambridge: Cambridge University Press.

Perry, A., N. Wadhams. 2011. Kenya’s banking revolution. Time. 31 Jan. 41-44.

Pitelis, C.N. 1993. Transnationals, international organization and deindustrialization, Organization Studies, 14(4): 561-582.

Pitelis, C.N. 1996. Effective demand, outward investment and in the (Theory of the) Ttansnational corporation: An empirical investigation. Scottish Journal of Political Economy, 43(2): 192-206.

Pitelis, C. 2000. A theory of the (growth of the) transnational firm: a Penrosean perspective. Contributions to Political Economy, 19(1): 71-89.

Pitelis, C. N. 2007a. A behavioral resource-based view of the firm: the synergy of Cyert and March (1963) and Penrose (1959). Organization Science, 18(3): 478-490. 
Pitelis, C. 2007b. Edith Penrose and a learning-based perspective on

the MNE and OLI, Management International Review, 47(2): 207-219.

Pitelis, C. N. 2009. The co-evolution of organizational value capture, value creation and sustainable advantage. Organization Studies, 30(10): 1115-1139.

Pitelis, C.N. 2011. Globalization, Development, and History in the Work of Edith Penrose, Business History Review, 85(1): 65-84.

Pitelis, C. 2012. Clusters, entrepreneurial ecosystem co-creation, and appropriability: a conceptual framework. Industrial and Corporate Change, 21(6), 1359-1388.

Pitelis, C. N. \& Teece, D.J. 2010. Cross-border market co-creation, dynamic capabilities and the entrepreneurial theory of the multinational enterprise. Industrial Corporate Change, 19(4): 1247-1270.

Porter, M. 1980. Competitive strategy: techniques for analyzing industries and competitors. New York: Free Press.

Porter, M. 1990. The competitive advantage of nations. London: Macmillan.

Priem, R. L., Butler, J. E., \& Li, S. (2013). Toward reimagining strategy research: retrospection and prospection on the 2011 AMR decade award article. Academy of Management Review, 38(4): 471-489.

Priem, R. L., Li, S., \& Carr, J. C. (2012). Insights and new directions from demand-side approaches to technology innovation, entrepreneurship, and strategic management research. Journal of Management, 38(1): 346-374.

Radjou N., Prabhu, J. \& Ahuja, S. 2012. Jugaad innovation: a frugal and flexible approach to innovation for the 21st century. New Delhi: Random House India.

Ramaswamy, V. \& Gouillart, F. 2010. The power of co-creation: Build it with them to boost growth, productivity, and profits. Free Press: New York.

Read, S., Dew, N., Sarasvathy, S.D. \& Wiltbank R. 2009. Marketing under uncertainty: The logic of an effectual approach. Journal of Marketing, 73: 1-18. 
Rycroft, C. 1972. Critical dictionary of psychoanalysis. Harmondsworth: Penguin.

Schumpeter, J.A. 1954. History of economic analysis. Oxford: Oxford University Press.

Shackle, G. L. S. 1972. Epistemics and economics: a critique of economic doctrines. Cambridge: Cambridge University Press.

Simon, H. A. 1947/1997. Administrative behaviour. New York: Free Press.

Sørensen, J.B. \& Fassiotto, M.A. 2011. Organizations as fonts of entrepreneurship. Organization Science, 22(5): 1322-1331.

Teece, D. J. 1976. Multinational corporation and the resource cost of international technology transfer. Cambridge, MA: Ballinger.

Teece, D. J. 1981. The market for know-how and the efficient international transfer of technology. The Annals of American Academy of Political and Social Science, 458(1): 81-96.

Teece, D. J. 1982. Towards an economic theory of the multiproduct firm. Journal of Economic Behavior and Organization, 3(1): 39-63.

Teece, D.J. 2007. Explicating dynamic capabilities: the nature and microfoundations of (sustainable) enterprise performance. Strategic Management Journal, 28(13): 13191350.

Theodosiou, M., \& Leonidou, L. C. 2003. Standardization versus adaptation of international marketing strategy: an integrative assessment of the empirical research. International Business Review, 12(2): 141-171.

Tolbert, P.S., David, R.J. \& Sine, W.D. 2011. Studying choice and change: the intersection of institutional theory and entrepreneurship research. Organization Science, 22(5): 13321344.

Tripsas, M. \& Gavetti, G. 2000. Capabilities, cognition and inertia: evidence from digital imaging. Strategy Management Journal, 21:1147-61.

Tsang, D. 2015. Entrepreneurial Creativity in a Virtual World. Cheltenham: Edward Elgar. 
Vernon, R. 1966. International trade and international investment in the product cycle. Quarterly Journal of Economics, 80: 190-207.

Weick, K.E. 1995. Sensemaking in organizations. Thousand Oaks, CA: Sage Publications.

Williamson, O. E. 1981.The economics of organization: the transaction cost approach. American Journal of Sociology, 87(3): 548-577.

Winter, S.G. 2006. The logic of appropriability: from Schumpeter to Arrow to Teece. Research Policy, 35(8): 1100-1106.

Witt, U. 2007. Firms as realizations of entrepreneurial visions. Journal of Management Studies, 44(7): 1125-1140.

Zald, M. N. 1996. More Fragmentation? Unfinished business in linking the social sciences and humanities. Administrative Science Quarterly, 41(2): 251-261.

Zaheer, S. 1995. Overcoming the liability of foreignness. Academy of Management Journal, 38(2): 341-363. 


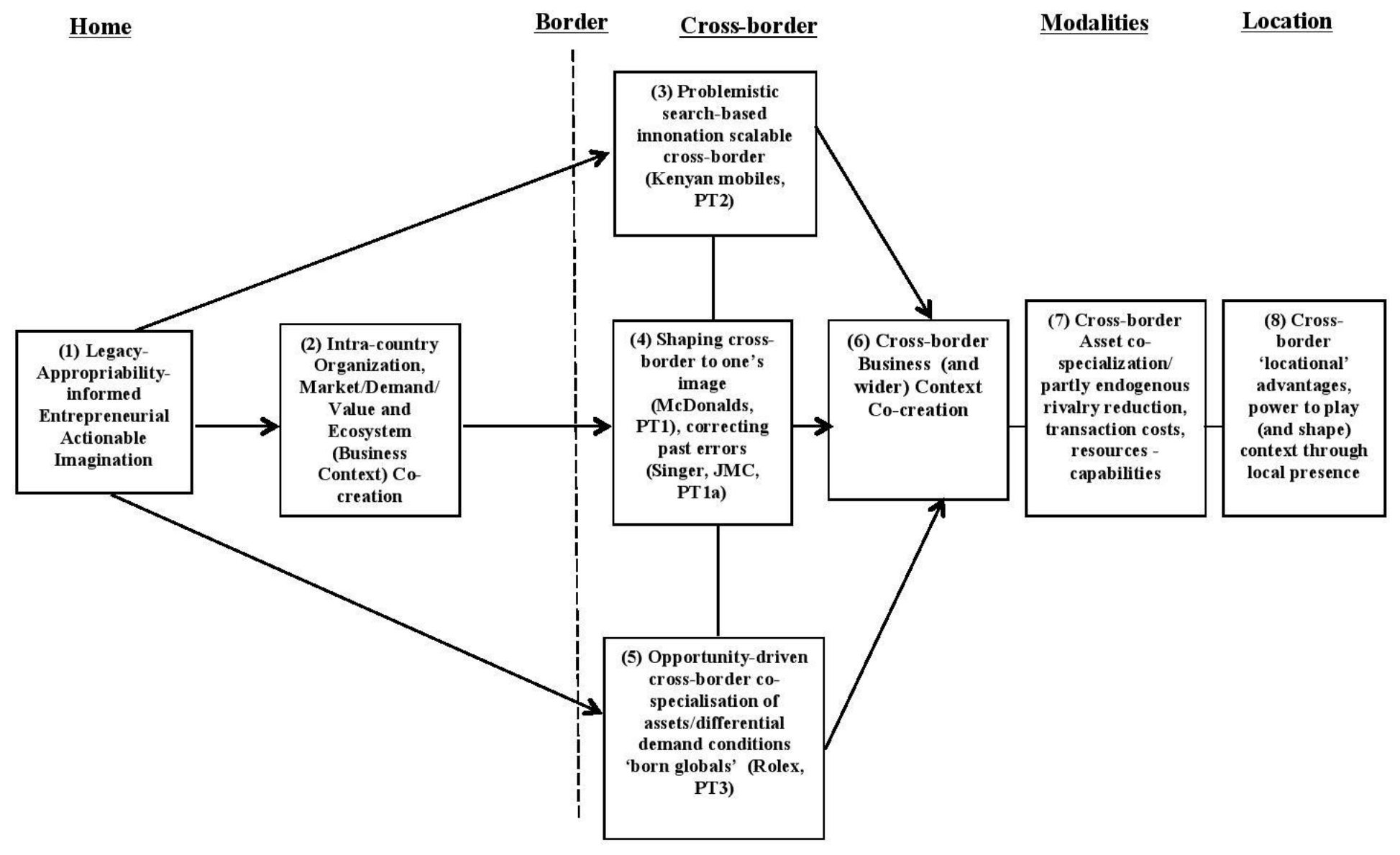

FIGURE 1.

Appropriability-Legacy-Informed Entrepreneurial Imagination, Cross-Border Expansion and Organisation and the MNE: A Framework 